\title{
Performance Clustering and Incentives in the UK Pension Fund Industry*
}

\author{
David Blake \\ Pensions Institute, Birkbeck College, University of London \\ Bruce N. Lehmann \\ IRPS, University of California, San Diego \\ Allan Timmermann \\ Economics Department, University of California, San Diego
}

July 9,2002

\begin{abstract}
Despite being largely unconstrained in their investment decisions, we find evidence of clustering in the performance of a large cross-section of UK pension fund managers around the median fund manager. We explain this finding in terms of: the predominance of a single investment style (balanced management), the fee structures and incentives operating in the UK pension fund industry to maximize relative rather than absolute performance, the high concentration in the UK pension fund industry and the low turnover of fund managers. Fund size appears to be the only variable that can account for an important fraction of the cross-sectional variation in measured performance.
\end{abstract}

\footnotetext{
${ }^{*}$ We would like to thank Gordon Bagot and Val Ashmore of The WM Company for advice on interpreting the data used in this study and Juan-Pedro Gómez and seminar participants at the INSEAD conference on institutional investors and financial markets in April 2001 for valuable comments on an earlier draft. The comments of Paul Yates and Andrew Maclaren of UBS Global Asset Management and three anonymous referees were also very helpful in revising the paper.
} 


\section{Introduction}

Despite the vast growth and increased economic importance of the fund management industry, few studies have considered the effect of incentives and fee structures on fund behavior. Further, what studies have been produced have almost exclusively focused on the investment behavior of US mutual funds, predominantly those invested in US equities. ${ }^{1}$ Investment performance by institutions outside the US has been much less intensively researched. This omission is important since differences in institutional and legal frameworks and, indeed, different investment cultures and fund manager compensation schemes might help to shed additional light on the incentive effects operating in this industry.

The few studies that consider fund manager behavior show the importance of incentive effects. In a careful empirical study of the incentives facing US mutual fund managers, Chevalier and Ellison (1997) and Sirri and Tufano (1998) document a nonlinear relationship between fund inflows and past relative performance. This relationship, which is particularly strong for young funds, provides different incentives for funds to assume idiosyncratic risk, depending on their past relative performance. Likewise, Brown, Harlow and Starks (1996) find that funds experiencing underperformance during the first half of an assessment period (usually a calendar year) have an incentive to load on additional idiosyncratic risk, while out-performing funds tend to 'lock in' their position and off-load risk, although this finding has recently been questioned by Busse (2001).

A closely related literature, e.g. Trueman (1994) and Zwiebel (1995), considers the effect of reputation on herding behavior. Zwiebel shows that when managers care about their reputation and there is asymmetric information about their ability, managers may abstain from risky investments that could lead to a deterioration in their measured relative performance. Empirical studies such as Chevalier and Ellison (1999) and Hong, Kubik and Solomon (2000) find that reputation effects can explain the unwillingness of security analysts and mutual fund managers to deviate from the median agent's decision.

Our paper contributes to this literature by examining the effect of incentives and fee structures on the cross-sectional distribution of investment performance

\footnotetext{
${ }^{1}$ Recent examples of studies that also consider US pension funds' behavior include Lakonishok, Shleifer, and Vishny (1992a), Coggin, Fabozzi, and Rahman (1993), and Christopherson, Ferson and Glassman (1998a,b).
} 
for a large sample of UK occupational pension funds over the period 1986-1994. ${ }^{2}$ The data were provided by The WM Company (a key performance measurement service in the UK). As in the US, UK pension fund managers typically underperform external benchmarks that represent feasible passive investment vehicles. Yet there are some striking differences between the fund management industries in the two countries. UK pension funds face a smaller set of constraints than their US counterparts. The industry is much more highly concentrated in the UK than in the US, turnover in fund managers is much lower, balanced fund management dominates, there is a smaller range of alternative investment styles, and relative performance evaluation at both the individual fund manager and fund management house $(\mathrm{FMH})$ levels has a more significant impact on investment strategies and outcomes. ${ }^{3}$ Since we have data on peer-group benchmarks, we can assess directly the empirical importance of relative performance evaluation emphasized by earlier studies. In particular, we find remarkably little cross-sectional variation in the average total or asset class returns, however adjusted for risk, of the funds in our sample; in the case of equities, the cross-sectional variation in the UK is only about half that of US pension fund managers. Only fund size can account for a nontrivial fraction of this distribution and then only in the case of UK equities. Furthermore, the distributions across asset classes are centred very close to (and slightly below in the case of key asset classes) the corresponding market indices: the underperformance of UK pension fund managers appears to be lower than that of their US counterparts.

Fee structures appear to provide a strong disincentive to undertake active management. UK pension fund managers are set the objective of adding value but their fees are generally related to year-end asset values, not directly to performance. Genuine ex ante ability that translates into superior ex post performance increases assets under management and, thus, the base on which the management fee is calculated. However, this incentive is not particularly strong and active management subjects the manager to nontrivial risks. The incentive is weak because the prospective fee increase is second order, being the product of the ex post return from active management and the management fee and thus around two full

\footnotetext{
${ }^{2}$ With a few exceptions (e.g., Brown, Draper and McKenzie (1997), Blake, Lehmann and Timmermann (1999), and Thomas and Tonks (2000)), the UK pension fund industry remains significantly under-researched.

${ }^{3}$ See, e.g., Lakonishok, Shleifer and Vishny (1992b) for evidence on the US market.
} 
orders of magnitude smaller than the base fee itself. Moreover, the ex post return from active management of a truly superior fund manager will often be negative and occasionally large as well, resulting in poor performance relative to managers who eschewed active management irrespective of their ability. The probability of relative underperformance large enough to lose the investment mandate is likely to be at least an order of magnitude larger than the proportional management fee. Hence, the potential consequences of underperformance (failure to renew the mandate) arising from poor luck outweighs the prospective benefits from active management (a slightly bigger fee) for all but the most certain security selection or market timing opportunities.

The structure of the paper is as follows. Section 3 investigates the cross-sectional variation in the performance of UK pension funds. The performance conditional on fund characteristics, such as size and past performance, is investigated in Section 4 , and Section 5 concludes. We begin with a brief review of incentives in the UK pension fund industry.

\section{Incentives and Fee Structures in the UK Pension Fund Industry}

Certain institutional features of the UK pension fund industry affect managerial incentives in important ways. First, UK pension fund managers face perhaps the smallest set of externally-imposed restrictions on their investment behavior of any group of institutional investors anywhere in the world. During the sample period, the funds being managed were, by and large, unconstrained by their liabilities: UK pension funds were running large actuarial surpluses until almost the end. The fund managers themselves are also largely unconstrained in their investment decisions by trustee sponsors who do not interfere in day-to-day operations ${ }^{4}$. They are unconstrained in their choice of investments: unlike many of their counterparts in continental Europe and elsewhere, they are free to invest in almost any class of asset, in any currency denomination and in any amount (although there

\footnotetext{
${ }^{4}$ Pension or investment consultants (such as Watson Wyatt or Frank Russell) are hired by trustees to help design the investment mandate and interview potential fund managers. But the final decision rests with the trustees. Once the mandate has been awarded, it typically lasts for three years. The trustees can cancel the mandate at any time before this if they are dissatisfied with their fund managers, although in practice the periodic reviewing process gives half a year's lead time.
} 
are statutory limits on self-investment in the sponsoring company and, on grounds of prudence, fund managers would limit the extent of currency mismatch of assets against sterling-denominated liabilities). Unlike their US counterparts, UK pension fund managers faced no substantive regulatory controls or real threat of litigation against imprudent investment behaviour during the sample period (Del Guercio (1996)). These differing sets of restrictions are reflected in different asset allocations: UK pension funds hold a far larger portfolio weight in equities and a lower weight in bonds than their US or continental European counterparts. The great attraction, therefore, of the WM data set is that, in principle, it enables us to identify the genuine investment skills of a group of fund managers in a way that is not possible with other data sets on investment performance generated under more restrictive conditions.

This investment freedom is moderated somewhat by the second institutional feature, namely the high degree of concentration in the UK fund management industry. Over the sample period, the top five $\mathrm{FMHs}^{5}$ accounted for 80 per cent of total assets under management (Lambert (1998)). This results in the asset allocations of a large number of pension funds being influenced by a small number of 'house views' on key economic and market conditions. In contrast, the US fund management industry is considerably less heavily concentrated with the top five FMHs accounting for just 14 per cent of total assets in 1990 (Lakonishok, Shleifer and Vishny (1992a, Table 12)).

One interesting feature of pension fund management in the UK is that there is rarely a change of $\mathrm{FMH}$, even if there is sometimes a change of mandate (e.g. requiring a change of benchmark): the average length of a pension fund investment mandate in the UK was 7.25 years over the sample period (Prosser (1995)). This is partly because of the expenses associated with a shift in management. But it is also partly because of reputation. As Kay et al. (1994) observe, there are two components to this. The first is trust, that is, confidence in the honesty and integrity of the manager, and the largest FMHs have the most secure reputations in this field. The second is good investment performance which is based on a consistent 'track record'. According to Kay et al. (op. cit), the largest FMHs use

\footnotetext{
${ }^{5}$ Merrill Lynch Investment (formerly Mercury Asset) Management, UBS Global Asset Management (formerly Phillips and Drew), Gartmore Pension Fund Managers, Deutsche (formerly Morgan Grenfell) Asset Management, and Schroder Investment Management.
} 
their track records to retain existing clients or to attract new clients, rather than to extract higher charges. In addition, UK pension fund trustees tend to place a high value on the service provided by the fund manager. Good service and a good personal relationship between the fund manager and the trustees can compensate for periods of poor investment performance and so also help to retain the mandate. Indeed, one fund manager informed us that fund managers do not get fired for past bad performance, but rather for lack of confidence in future performance that might be signalled, for example, by major changes in personnel or systems, or because major clients begin to leave.

This leads directly to the third institutional feature: the long-term survival of fund managers is determined by their relative performance against their peer-group rather than by their absolute performance. Even if all fund managers performed badly in a particular year, managers who appear in the upper quartile will still be regarded as relatively good. No potential new managers will be invited to join the 'beauty contest' for a mandate renewal unless they have enjoyed a good relative performance record over the previous three years. Similarly, managers with persistent poor relative performance will eventually lose their mandates. This has been clearly demonstrated in recent years as the persistent underperformance of some of the larger active FMHs has resulted in major clients switching to index fund managers. ${ }^{6}$

Finally, most UK pension fund managers earn fees related solely to the value of assets under management, and not to their relative performance against either a predetermined benchmark or their peer-group (i.e., there is typically no specific penalty for underperforming and no specific reward for outperforming an explicit benchmark). In the case of balanced management, the fee is proportional to the value of the fund and therefore rises as the fund manager adds value. However, specialist mandates tend to be more directly performance-related than balanced mandates. The fee in this case involves a value-related component which is designed to cover the fund manager's costs plus a component that is related to the fund's outperformance of a prespecified benchmark.

To get some notion of the size of the fees charged by UK pension fund managers, we obtained the fee structure of three major UK fund managers. Merrill Lynch

\footnotetext{
${ }^{6}$ E.g., Barclays Global Investors and Legal \& General.
} 
Investment Management's ${ }^{7}$ management fee for balanced, segregated funds is as follows (reported in Kay et.al. (op.cit.)). For funds up to $£ 50 \mathrm{~m}$ in value: 0.75 per cent on the first $£ 1 \mathrm{~m}, 0.5$ per cent on the next $£ 4 \mathrm{~m}, 0.3$ per cent on the next $£ 5 \mathrm{~m}$, and 0.15 per cent on the next $£ 40 \mathrm{~m}$. For funds between $£ 50 \mathrm{~m}$ and $£ 100 \mathrm{~m}, 0.175$ per cent on the first $£ 50 \mathrm{~m}$ and 0.15 per cent on the next $£ 50 \mathrm{~m}$. For funds between $£ 100 \mathrm{~m}$ and $£ 200 \mathrm{~m}$ : 0.15 per cent. For funds greater than $£ 200 \mathrm{~m}$ : negotiable. Gartmore's management fee is as follows: 0.5 per cent on the first $£ 25 \mathrm{~m}, 0.3$ per cent on the next $£ 50 \mathrm{~m}, 0.2$ per cent thereafter; the fee is negotiable above $£ 150 \mathrm{~m}$. The fees of another large fund management group (which asked not to be identified) are: 0.5 per cent on the first $£ 20 \mathrm{~m}, 0.3$ per cent on the next $£ 30 \mathrm{~m}, 0.25$ per cent on the next $£ 50 \mathrm{~m}$, and 0.175 per cent thereafter. So although the marginal fee is falling, the total fee is weakly performance-related because it increases with the value of the fund (in practice, the fee is paid quarterly depending on the value of the fund at the end of each quarter). Comparable figures for the US reported in Lakonishok, Shleifer and Vishny (1992a, p. 371) are 0.6 per cent for a $\$ 25 \mathrm{~m}$ account (with an interquartile range of $0.52-0.70$ per cent) and 0.53 per cent for a $\$ 50 \mathrm{~m}$ account (with an interquartile range of $0.43-0.56$ per cent). Larger funds can, of course, negotiate lower fees (Halpern and Fowler (1991)).

UK pension fund managers therefore face the following incentives:

(1) They have an incentive to add value and they are largely unconstrained in the way in which they do this. The strategic asset allocation is set by the trustees (on the advice of investment or actuarial consultants); however there are tolerance limits around the SAA, which can in most cases be renegotiated, so that these limits are flexible and effectively non-enforced.

(2) In the short term (during the course of the current mandate), their fee is directly related to the fund value they achieve and not to either their value added or their relative performance against either a predetermined benchmark or their peer-group.

(3) They have to bear in mind that it is their relative performance against their peer-group rather than their absolute performance that determines their long-term survival in the industry. ${ }^{8}$

\footnotetext{
${ }^{7}$ At the time the company was named Mercury Asset Management.

${ }^{8}$ Further details of the investment environment faced by UK pension funds during the late 80s and early 90s are contained in Stevenson (1993) and Blake (1995). See Lakonishok et al (1992a) for a comparative analysis of the incentives operating in the US pension fund industry.
} 
The unconstrained way in which UK pension funds are permitted to add value under (1) might induce different fund managers to pursue very different investment strategies and this might, in turn, lead to a wide dispersion in investment performance. On the other hand, the weak incentive to add value under (2) and strong incentives under (3) to avoid relative underperformance might cause fund managers to pursue very similar investment strategies (behavior known as 'herding') which can result in a narrow distribution of investment performance. The following sections attempt to identify which effect dominates.

\section{The Performance of UK Pension Funds}

The data from WM consists of monthly observations on the returns of $306 \mathrm{UK}$

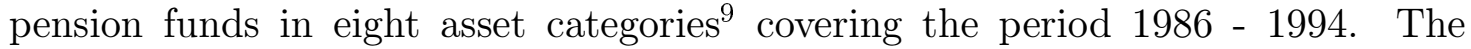
returns are net of the bid-offer spread, but before management and research fees are taken into account. The sample is complete in the sense that it contains all of the funds with no missing data that maintained the same single, externally-appointed FMH throughout the period. We examine the total returns on the portfolios, as well as the separate returns within the eight asset classes. As benchmarks for evaluating performance, WM uses both external, independently calculated indices (e.g., the Financial Times Actuaries (FTA) All-Share Index for UK equities), as well as WM universe indices based on value-weighted portfolios of the population of funds tracked by $\mathrm{WM}^{10}$. The latter peer-group indices are commonly used by the industry to assess funds' medium- to long-term relative performance.

To our knowledge, this is the first study to consider herding in the context of a multi-asset portfolio. We have data on the value of asset holdings as well as returns, in contrast with some earlier studies of US pension funds where only returns data was available (Christopherson, Ferson and Glassman (1998a,b)). Having access to this type of data could make a big difference to the empirical results. For example, Lakonishok, Shleifer and Vishny (1992b) find only weak evidence of herding effects and mainly so for small firm stocks. Commenting on this, Zwiebel (1995, p. 2) notes that "... herding is more likely over broader investment categories (stocks, bonds,

\footnotetext{
${ }^{9} \mathrm{UK}$ and international equities, bonds and property and UK index bonds and cash/other investments.

${ }^{10}$ The WM universe contains all the funds tracked by WM, including both surviving and nonsurviving funds.
} 
real estate, foreign investments, etc.) than over individual stocks. Lakonishok et al. do not test for such broad-based herding."

Another virtue of the UK study concerns the nature of the benchmarks used to correct for systematic risk. Benchmark inefficiency is a central theme of both the theoretical and empirical literatures on performance evaluation, because of the difficulty in distinguishing benchmark inefficiency from abnormal performance. As an empirical matter, Lehmann and Modest (1987), Grinblatt and Titman (1989), and Elton, Gruber, Das, and Hlavka (1993) have found that measured US equity mutual fund performance can depend critically on the benchmark used in the analysis. Elton, Gruber, Das, and Hlavka (op. cit.) and Ferson and Schadt (1996) highlight some of the misspecification problems associated with performance measurement that arise when the funds under consideration hold assets, such as international equities and bonds, that are excluded from the benchmark index. ${ }^{11}$ Our data permit us to deal with some of these issues. Since we know the structure of the asset allocations of the included pension funds, we can use benchmarks that do not suffer from defects of asset coverage. That is, we can compare asset-class returns with suitable asset-class benchmarks in both unconditional and conditional single-index models and with appropriate multiple-index benchmarks that represent all of the different asset categories actually held by the pension funds.

Table 1 presents some regularities in average fund performance. Panel A provides key fractiles and the minimum and maximum of the cross-sectional distribution of average total returns on the seven most important asset classes as well as on the total portfolio. The interquartile range runs from 11.47 percent to 12.59 per cent per year and less than 300 basis points separates the funds in the 5 th and 95th percentiles. To be sure, there is somewhat greater cross-sectional variability in particular asset classes. For example, the interquartile range for UK equity returns is of the order of 150 basis points and the corresponding 5th-95th percentile range is 400 basis points. The corresponding ranges are larger for international equity returns, with an interquartile range of more than 200 basis points and a 5th-95th percentile range of 450 basis points.

This comparatively narrow range of cross-sectional variability suggests that any

\footnotetext{
${ }^{11}$ Elton, Gruber, Das and Hlavka (1993) found that the inclusion of a bond index and a small cap equity index substantially altered the performance in their analysis of a large universe of US mutual funds.
} 
differences in performance ability across the funds in our sample should show up conditionally since an unconditional distribution with low variability can conceal highly variable distributions once nontrivial conditioning information is taken into account. However, Panel B of Table 1 shows that the requisite variability does not emerge from simple risk-adjustment procedures such as basic Jensen regressions:

$$
r_{i j t}-r_{f t}=\alpha_{i j t}+\beta_{i j t}\left(r_{m j t}-r_{f t}\right)+\epsilon_{i j t}
$$

where $r_{i j t}$ is the return on the i'th fund's j'th asset class in period $\mathrm{t}, r_{f t}$ is the return on a one-month T-bill, and $r_{m j t}$ is the return on the $j$ 'th external index in period t. In this panel, the Jensen $\alpha_{i j t}$ and $\beta_{i j t}$ are time-invariant. As is readily apparent the shape of the cross-sectional distribution of the alphas is virtually identical to that of raw average returns across funds in each asset class and for the aggregate portfolio. For all asset classes with portfolio weights exceeding five per cent and for the overall portfolio the interquartile ranges of the sample Jensen alphas are within about five percentage ponts of those of the corresponding average returns.

Furthermore, the performance of the median fund manager is very close to that of the external index (just 15 and 14 basis points, respectively, below in the case of the equity and total portfolios). This suggests not only that our sample of fund managers clustered around the median fund manager, but also that the median fund manager, despite both claiming to be and paid to be an active fund manager, behaves like a closet index matcher. The degree of underperformance by pension fund managers is much greater in the US, 130 basis points in the case of US equities according to Lakonishok, Shleifer and Vishny (1992a, p.348). ${ }^{12,13}$

In general, we would not expect relative rankings to change much whether

\footnotetext{
${ }^{12}$ While their sample period (1983-1990) is similar to ours (1986-1994), these results are not directly comparable since the data sets do not coincide. However the samples do contain five overlapping years and the market environments in the non-overlapping years would have to be very different to render the comparison invalid.

${ }^{13}$ Lakonishok, Shleifer and Vishny found this degree of underperformance using a benchmark of large-cap stocks (S\&P500). Christopherson, Ferson and Glassman (1998b), in contrast, found no evidence of underperformance using investment style benchmarks such as growth, value, largecap or small-cap. However, their returns data are equally-weighted as they have no information on fund size and this will impart an upward bias if, as we find, large funds underperform small funds. Like ours, the Lakonishok, Shleifer and Vishny dataset is value-weighted, suggesting that our finding of greater underperformance by the median fund manager in the US than in the UK (against a similar aggregate benchmark) is both valid and economically significant.
} 
we rank on the basis of average returns, mean-adjusted returns or on conventional Jensen alphas. Consequently, any diligent search for abnormal performance in these funds must consider alternative risk-adjustment procedures. The next subsection provides a detailed examination of the domestic equity portfolios of our funds using Jensen-style regressions that permit time-varying alphas and betas. This focus on the equity component facilitates comparison with the existing academic literature which mainly covers equity mutual funds. In addition, domestic equities is the most important asset class, accounting for more than half of the aggregate pension fund portfolio and for an even greater fraction of its performance. The subsequent subsection reports ex post performance measures from basic Jensen regressions for the other asset categories and from a multiple-index Jensen regression for the total portfolio on the grounds that this is likely to be more appropriate for the aggregate portfolio.

\subsection{UK Equity Performance against Single-Index Benchmarks}

We investigate UK equity fund performance with five versions of (1). The first is the original Jensen regression with time-invariant alphas and betas, which provides performance measures conditional only on differences in unconditional betas. Second, we follow Ferson and Schadt (1996) by permitting betas to vary over time, allowing for predictable variation in risk exposures and, implicitly, in benchmark returns, on the grounds that managers should not be credited for performance based on changing portfolio weights in the light of costless public information. ${ }^{14}$ Third, we allow for predictable variation in alphas as well, as in Christopherson, Ferson, 
Mazuy (1966), we added the squared excess benchmark return to the unconditional Jensen regression since all the above procedures are suspect if managers possess market timing ability. If managers possess market timing ability, they should earn positive excess returns when benchmark returns are large in absolute value, while selection skills should show up as positive alphas in the absence of benchmark error under plausible assumptions. ${ }^{16}$

The behavior of the Jensen alphas from these models should differ depending on the nature of the underlying economic environment and the hypothesized market timing ability of managers. If the investment opportunity set is unchanging (that is, if benchmark returns and their first few moments are time-invariant) and managers have no market timing ability, all models using the same benchmark will produce alphas and betas with the same expected values. In particular, the cross-sectional distribution of the alphas should be identical across models, holding the benchmark constant. The interpretation is more problematic if the investment opportunity set is time-varying (that is, if the mean, volatility, and, perhaps, higher moments of the benchmark returns exhibit predictable variation). The Jensen alphas and betas will be biased estimates of their unconditional means in this case if fund betas move with the relevant conditional moments of the benchmark return, even if managers possess no market timing ability. Hence, conditioning on public information, as in the second and third models and on the squared excess market return as in the fifth model, can materially alter the distribution of the alphas to the extent that betas are negatively correlated with population alphas. Finally, conditioning on public information might eliminate some of the cross-sectional variation in measured alphas to the extent that fund betas are correlated with conditional market risk premiums and volatilities.

Table 2 reports a number of summary statistics describing the cross-sectional distribution of the alphas from these models. We provide several fractiles of their distribution as well as their maximum and minimum values and their associated Bonferroni probability values (p-values). ${ }^{17}$ We also present the mean alphas and

\footnotetext{
${ }^{16}$ See, e.g., Jensen (1972), Admati, Bhattacharya, Pfleiderer, and Ross (1986), Lehmann and Modest (1987), and Grinblatt and Titman (1989)

${ }^{17}$ Since the t-statistics of these alphas are interdependent and there are more alphas than time series observations, we cannot construct a joint test of their significance. Moreover, the joint test has low power if a small subset of the alphas differs from zero in the population, as we would expect $\mathbf{d}$ suru on the hypothesis that abnormal performance is not pervasive. For both reasons,
} 
associated t-statistics. ${ }^{18}$

Several regularities emerge from these models. With the exception of the last column of Table 2, average performance is economically and statistically negligible, the largest alpha estimate (that for the Christopherson-Ferson-Glassman model) being only 33 basis points annualized. Similarly, the fraction of funds with positive alphas is less than 50 per cent for all models, again apart from the ChristophersonFerson-Glassman model for which 58 per cent of the estimates were positive, with just 8 per cent of these were significant at the 5 per cent level. In addition, the most extreme outperformer and underperformer had one-sided t-statistics with Bonferroni p-values well below the 0.0001 level, except for the marginal significance level of 0.015 for the largest outperformer identified by the Ferson-Schadt model. The effect of taking time-varying alphas and betas into account is to reduce or leave unchanged the number of statistically significant positive and negative alpha values. Taken together, and ignoring any concern for benchmark error and survivor bias, there is little evidence of abnormal performance on average in this industry or indeed much evidence of extreme out- or underperformance that is significant at any reasonable level.

The main regularity concerns the shape of the cross-sectional distribution. The annualized interquartile range in each of these models is about 150 basis points, virtually identical to that of raw UK equity returns at 149 basis points. Conditioning on alternative models for beta changes the location of the cross-sectional distribution of raw returns, but leaves its shape virtually unchanged. Pension funds with similar performance by any of these measures also have similar risk exposures. Moreover, any shifts in their betas had sufficiently low correlations with benchmark returns or publicly-available conditioning information as to leave the cross-sectional distribution of the ex post alphas unchanged. ${ }^{19}$ Market timing switches among asset

we report p-values based on the Bonferroni inequality, which in this case states that the marginal significance level of the largest t-statistic in absolute value is less than $\pi$ when its p-value is $\pi / \mathrm{N}$, where $\mathrm{N}$ is the number of t-statistics examined simultaneously.

${ }^{18}$ Following Fama and MacBeth (1973), the standard error of this average alpha was computed from the time series of returns on the equal-weighted portfolio; we ignore the small downward bias associated with the omission of the sample squared Sharpe ratio of the index, c.f. Shanken (1992).

${ }^{19}$ The cross-sectional variation in the unconditional betas was trivial as reflected in the interquartile range in sample betas of 0.99 to 1.01 , a range that we would expect if closet index matching was a significant practice. Also, the location of the individual alpha estimates within 
classes do not contribute materially to cross-sectional variation in average equity returns within the UK pension fund industry.

Of course, UK managers are evaluated relative to peer-group benchmarks, not explicitly by any risk-adjustment procedure. We replicate WM's performance evaluation methodology by comparing the UK equity performance with that of the WM2000 UK Equity Index $\left(r_{m j t}^{*}\right):^{20}$

$$
\alpha_{i j t}=r_{i j t}-r_{m j t}^{*}
$$

In contrast with the previous methods, the peer-group approach requires no estimation of risk exposures, since it implicitly sets $\beta_{i j t}$ to unity. Recent empirical evidence (e.g. Brown, Harlow, and Starks (1996) and Chevalier and Ellison (1997)) suggests the importance of relative performance evaluation for US equity managers as well. The final column of Table 2 reveals that this UK pension fund industry practice significantly alters the appearance of managerial effectiveness. Nearly two-thirds of the funds (mainly the smaller ones) ${ }^{21}$ outperformed the relative (value-weighted) equity benchmark with 48 funds (16 per cent of the total) having relative performance alphas that are significant at the 5 per cent level. Many fewer funds earned negative alphas and fewer than 15 of these were significant at the 5 per cent level. Average performance was positive: the mean alpha estimate was 0.459 per cent per year with a t-value of 4.04 . Of course, relative performance evaluation only changes the location of the cross-sectional distribution of raw average returns, leaving the shape unchanged.

Finally in this section, we can compare our results with those found by Coggin et al. (1993, p1051) for US equity pension fund managers using the Treynor-Mazuy model $^{22}$. We find a spread between the 10th and 90th percentiles for UK equities of 3.11 per cent. Coggin et al., in contrast, found a spread between the 10th and 90th percentiles of between 5.84 and 6.03 per cent (depending on the benchmark),

their cross-sectional distribution proved quite robust across risk-adjustment procedures. For example, using the unconditional and the conditional Jensen procedures, the cross-sectional rankcorrelation between the funds' mean (raw) excess returns and their alpha estimates was 0.99 and 0.88 , respectively.

${ }^{20}$ This is a value-weighted index of all the funds tracked by WM, except for the very large funds which have their own WM50 index.

${ }^{21}$ The effect of fund size on performance is examined in Section 4.

${ }^{22}$ Their sample period (1983-1990) is similar to ours (1986-1994), but not coincident. 


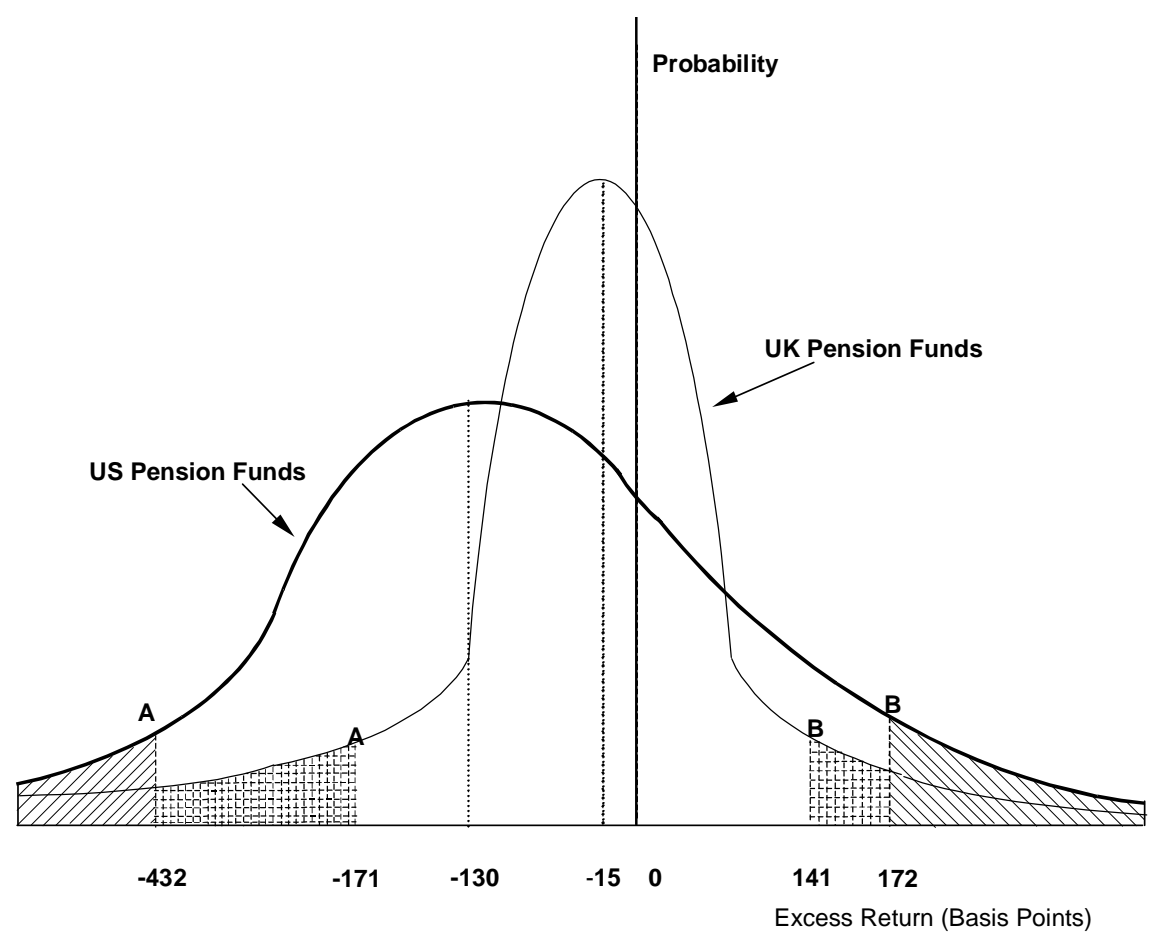

Figure 1: The Dispersion of Excess Equity Returns on UK and US Pension Funds. Note: $\mathrm{A}=10$ th percentile; $\mathrm{B}=90$ th percentile.

almost double that in our sample. As is readily apparent, there is remarkably little cross-sectional variation in annualized total returns in our sample compared with the US results: see also Figure 1.

\subsection{Performance in Other Asset Categories and the Total Portfolio}

We conducted comparable analyses across asset classes with single-asset class benchmarks and obtained findings similar to those reported for UK equity, c.f. Panel $\mathrm{B}$ in Table $1 .^{23}$ That is, the average Jensen alpha sometimes varied across riskadjustment procedures, but the shape of the cross-sectional distribution of ex post performance measures remains largely unchanged and thus very similar to that of raw and mean-adjusted returns. Since we have data on asset-class-specific bench-

\footnotetext{
${ }^{23}$ We did not fit versions of time-varying beta models or of Treynor-Mazuy regressions here since either approach would greatly increase the number of parameters, straining an already modest-sized sample.
} 
marks, we use the multi-factor version of the standard Jensen regression for the total portfolio, comparing the excess total return of the $i$ 'th fund with the excess returns on the entire set of indices:

$$
r_{i p t}-r_{f t}=\alpha_{i p}+\sum_{j=1}^{M} \beta_{i j}\left(r_{m j t}-r_{f t}\right)+\epsilon_{i p t},
$$

where $M$ is the number of asset classes for which a benchmark index is available. ${ }^{24}$ Hence $\alpha_{i p}$ is the multi-factor analogue of the standard Jensen measure and the potential pitfalls arising from market timing ability parallels that in the single index case.

Overall, UK pension fund managers tended to slightly underperform in our sample: 138 funds had positive alphas with only 9 (3 per cent of the total) significant at the 5 per cent level and 168 funds had negative alphas, of which 6 (2 per cent) were similarly significant. Their interquartile range ran from -0.71 per cent to 0.44 per cent, an annualized range (of 115 basis points) that differed from that of the raw returns by only three basis points (c.f. Table 1). The alpha estimate for the equally-weighted portfolio was a minuscule -0.11 per cent, with a t-value of -0.17 . The left tail of the cross-sectional distribution is neither long nor dense and the Bonferroni p-value for the most underperforming fund had a marginal significance level of only 0.62. Only the Bonferroni test statistic for the most successful fund is suggestive of abnormal performance, with a p-value less than 0.00001, indicating sharp rejection of the null of no outperforming funds at any conventional level. Of course, this rejection could still reflect benchmark error and survivor bias as well. ${ }^{25}$

Relative performance evaluation for the overall portfolio parallels that of the equity case: 197 (mainly smaller) funds (64 per cent) outperformed the peer-group benchmark, 41 (13 per cent) significantly so at the 5 per cent level. Average fund performance was quite close to that of the peer-group benchmark, being an economically and statistically negligible 6 basis points below, but underperformed the external benchmark by a more substantial 45 basis points.

\footnotetext{
${ }^{24}$ Benchmarks were available for UK and international equities and bonds, UK index bonds, cash and UK property, but not for international property over the sample.

${ }^{25}$ As noted earlier, the asset class benchmarks might have biases associated with value weighting and asset coverage, country coverage in the case of international securities, and sector coverage in the case of domestic securities.
} 


\subsection{Testing and Correcting for Survivor Bias}

A potential problem with our data set is the survivor bias induced by the restriction to funds that maintained the same FMH over the whole period which is nearly two years longer than the average length of tenure of a pension fund management house in the UK. ${ }^{26}$ Funds were excluded from the sample supplied to us for one of five reasons. First, funds that switched FMHs are excluded from the sample, potentially the most pernicious source of survivor bias. Second, company takeovers often mean that funds are merged and merged funds are excluded. Third, funds might withdraw themselves from the WM measurement service with no explanation. Fourth, funds that switched from in-house to external management are eliminated because this constitutes a change in management. Fifth, some FMHs permit WM to measure only a proportion of the funds in their stable in order to save costs and occasionally they will rotate these funds, a practice called 'dynamization', and such funds are dropped from our sample. The last four sources are often independent of actual performance, so the elimination of funds from the universe often occurs for reasons that do not induce survivor bias.

To address this concern, we compared the value-weighted total returns of the funds in our sample by asset class and in aggregate with the corresponding valueweighted returns of the entire population of funds in the WM universe (1034 at the end of 1994). There was no systematic tendency for the returns in our sample to exceed those in the whole WM universe, either year-to-year or on average: in fact, the average return on our sample of funds was just 6 basis points below the WM universe. If survivor bias was pernicious, we would expect to observe such outperformance, particularly towards the end of the sample as the omitted returns from managers dropped due to poor performance are subtracted from returns in the whole universe but not from those of our sample.

A final reason why survivor bias does not appear to be an important issue in our sample can be gleaned from a comparison of the evolution of the portfolio weights of the funds in our sample with those in the WM universe. The aggregate

\footnotetext{
${ }^{26}$ See Brown and Goetzmann (1995), Brown, Goetzmann, Ibbotson, and Ross (1992), Grinblatt and Titman $(1989,1992)$, and Malkiel (1995). There is no consensus regarding the magnitude of survivor bias. Malkiel finds that it can account for mean returns of as much as 1.5 per cent per annum, while Grinblatt and Titman (1989) estimate the effect to be somewhat smaller at 0.4 of a per cent per year.
} 
asset allocations in our sample and in the WM universe were nearly always within one percentage point of each other for each asset class and for each year, ${ }^{27}$ which explains the similarity in the performance of the two groups each year and indicates that both sets of managers followed similar market timing strategies. So the mean returns in the sample do not appear to be significantly affected by survivor bias. However, it is possible that survivor bias affects the dispersion of returns.

To investigate this possibility, we conducted an examination of the asymmetry of the tails of the distribution of performance estimates. The elimination from the sample of funds with large negative returns will both lower the overall dispersion of returns and lead to the left tail of the distribution of returns being thinner than the right tail. This is evident from panel A of Table 1 in the case of UK equities (the 5-50 per cent range is 1.70 per cent, while the $50-95$ per cent range is 2.33 per cent), US equities (the corresponding ranges are 2.06 per cent and 2.49 per cent) and cash/other investments (4.79 per cent and 5.88 per cent). However, the left tail is thicker than the right tail in the case of UK bonds (1.35 per cent and 1.26 per cent), international bonds (9.19 per cent and 6.78 per cent), UK index bonds (1.02 per cent and 0.67 per cent), UK property (3.68 per cent and 2.61 per cent) and, most significantly, for the portfolio as a whole (1.46 per cent and 1.33 per cent). So, in general, we can conclude that survivor bias does not appear to have affected dispersion of returns in any important way.

We also conducted a more formal econometric analysis which allows us to estimate the likely effect of survivor bias on the estimated Jensen measure. ${ }^{28}$ The idea is simple: funds whose risk-adjusted performance is large and negative are likely to be excluded from our sample since these funds are least likely to have their investment mandate renewed. One way to model this effect is by assuming that the sample of funds that we observe is a subsample of funds that avoided risk-adjusted performance below a certain level, $\kappa$. Suppose that the density of

\footnotetext{
${ }^{27}$ For example, in 1986 these weights were (for our sample and the WM universe (in brackets) respectively) as follows: UK equity: 54 (54), international equity 22 (22), UK bonds 5 (6), international bonds 3 (4), index bonds 4 (4), cash 4 (4), UK property 8 (6), international property $0(0)$.

${ }^{28}$ Our procedure is similar to methods for dealing with parameter biases introduced by data truncation (Greene (1999)). However, while the standard procedure assumes that the truncation is based on the value of the independent variable, which in our case would be $r_{i j t}-r_{f t}$, we modify this case by instead assuming that the truncation is determined by low risk-adjusted performance.
} 
the fund-specific performance component, $\varepsilon_{i j t}$, is normal with a mean of zero and a variance of $\sigma_{i j}$. Then the density of this component conditional on risk-adjusted performance, $\alpha_{i j}+\varepsilon_{i j t}>\kappa$ is simply:

$$
f\left(\varepsilon_{i j t} \mid \alpha_{i j}+\varepsilon_{i j t}>\kappa\right)=\frac{\frac{1}{\sigma_{i j}} \phi\left(\frac{r_{i j t}-r_{f t}-\alpha_{i j}-\beta_{i j t}\left(r_{m j t}-r_{f t}\right)}{\sigma_{i j}}\right)}{1-\Phi\left(\frac{\kappa-\alpha_{i j}}{\sigma_{i j}}\right)},
$$

where $\phi($.$) and \Phi($.$) are respectively the density and cumulative density functions$ of a standard normal variable. As a result of this conditioning effect, the mean of the $i$ 'th fund's risk-adjusted performance in the $j$ 'th asset class is no longer a linear function of $\alpha_{i j}$ :

$$
E\left[r_{i j t}-r_{f t}-\beta_{i j t}\left(r_{m j t}-r_{f t}\right) \mid \alpha_{i j}+\varepsilon_{i j t}>\kappa\right]=\alpha_{i j}+\sigma_{i j} \frac{\phi\left(\frac{\kappa-\alpha_{i j}}{\sigma_{i j}}\right)}{1-\Phi\left(\frac{\kappa-\alpha_{i j}}{\sigma_{i j}}\right)} .
$$

This is clearly a highly non-linear expression in $\alpha_{i j}$. Under the assumed density of $\varepsilon_{i j t}$, estimation of the parameters involves maximizing the log likelihood function:

$$
\begin{aligned}
\ln \left(L_{i j}\right)= & -\frac{T}{2}\left\{\ln (2 \pi)+\ln \left(\sigma_{i j}^{2}\right)\right\}-\frac{1}{2 \sigma_{i j}^{2}} \sum_{t=1}^{T}\left(r_{i j t}-r_{f t}-\alpha_{i j}-\beta_{i j}\left(r_{m j t}-r_{f t}\right)\right)^{2} \\
& -\sum_{t=1}^{T} \ln \left(1-\Phi\left(\frac{\kappa-\alpha_{i j}}{\sigma_{i j}}\right)\right) .
\end{aligned}
$$

Although far more involved than ordinary least squares estimation, the log likelihood function can be maximised for a given level of the performance truncation point, $\kappa$. We set this to $\kappa=-1$ per cent and $\kappa=-5$ per cent per month which are reasonable low and high bounds on the point at which risk-adjusted underperformance might expect to lead to a fund being dropped from the sample. If the proportion of funds with performance below $\kappa$ is low, then the second term on the right-hand side of (5) will be small and the estimates of risk-adjusted performance will not change significantly.

Results from undertaking this analysis on UK equities and the total portfolio are presented in Table 3. When $\kappa=-1$ per cent, survivor bias has two effects on the performance estimates. First, the median fund's performance in UK equities is reduced slightly from -0.15 per cent per annum to -0.17 per cent per annum. For the total portfolio a similar reduction in the median fund's performance from -0.14 per cent to -0.16 per cent per annum is observed. Second, the worst fund's 
performance is no longer -4.59 per cent in UK equities but a somewhat larger -4.74 per cent. For the total portfolio, the worst fund's performance is extended from -4.98 per cent to -5.15 per cent per annum. In comparison, censoring at $\kappa=-5$ per cent makes a negligible difference.

Overall, the conclusion that clearly emerges from Table 3 is one of robustness of our results with regard to this correction for survivor bias. In particular, the spread between the performance of the bottom 5 per cent and top 5 per cent of funds is remarkably stable and changes by no more than a single basis point for both UK equity and the total portfolio.

\section{Performance and Fund Characteristics}

The preceding results reveal two key features of abnormal performance in the UK pension fund industry. First, a variety of benchmark corrections suggests that few funds have robustly measured extreme abnormal performance. The second feature strikes us as of greater economic significance: the shape of the cross-sectional distribution of average raw total and asset class returns are broadly unaffected by risk adjustment, with even extreme ranges such as the 5th-95th percentile spread virtually unchanged. Cross-sectional variation in risk exposures does not appear to conceal cross-sectional variation in abnormal performance.

Perhaps fund performance is related to other fund attributes. We consider two natural and related candidates: size and past performance. The former might generate diseconomies of scale in asset management due to market impact, while the latter is not readily detectable using the methods of the previous section. If both prove to be related to abnormal performance, separating these effects involves recognizing that current size can be related to past performance.

\subsection{Fund Size Effects}

A finding that larger funds tend to underperform the peer-group would add credence to the often-made claim that size is the anchor of performance. Accordingly, we formed equally-weighted portfolios based on quartiles sorted according to the value of assets under management at the beginning of each year, starting with the smallest funds. This procedure generated four time series of portfolio returns for each asset class, the abnormal performance of which is presented in Table 4. Panel 
A suggests that, based on multi-index Jensen regressions, a size effect is present, most clearly for UK equities. The smallest-fund quartile has a positive alpha and the largest a negative alpha, neither of which is significantly different from zero at conventional levels, but the difference between them ( 0.79 per cent) has a t-statistic of 3.33 and an associated significance level of less than 0.001. ${ }^{29}$ Panel B confirms these results using relative performance measurement. Each portfolio has positive mean excess returns relative to the peer-group benchmark, rising from an economically and statistically insignificant 2.7 basis points per year for the large-fund portfolio to 72 basis points per year for the small-fund portfolio. The remaining asset classes reveal no clear pattern save for international bonds and equities, which suggest a direct, rather than an inverse, relationship between fund size and Jensen alpha. ${ }^{30}$ Perhaps most importantly, there is no systematic relationship between fund size and abnormal performance for the aggregate pension fund portfolios.

Nevertheless, the finding of an inverse relationship between fund performance and fund size in UK equities could be an important part of the explanation for mandate retention. UK pension funds hold a very substantial proportion of total issued domestic equities and large UK funds hold large fractions of their portfolios in UK equities as well. These funds can surely argue that an annual underperformance of the order of 70 basis points reflects the impact of the trading of large funds in a market in which they are important players.

Another possibility is that large funds do not actually underperform relative to smaller ones once management charges are taken into account. To explore this point, we calculated management fees based on the major FMHs' commission schedules. The management fee on a very small fund is of the order of 50 basis points per year while a very large fund would typically be charged 10 or fewer 
interest to ascertain whether it is size itself or whether there is a past-performance component driving the negative relation between fund size and performance in UK equities. $^{31}$

We adopted two approaches to maintain comparability with both the literature and the evidence given above. In the first, we examine the relation between future and past rankings of relative portfolio returns without adjusting for their correlation with one or more indices, an appropriate approach for investors with the bulk of their wealth invested in a single pension scheme. In the second approach, we investigate the persistence of Jensen measures obtained from average asset class returns after correcting for their correlation with the multiple-index benchmark, a more appropriate method for investors with only a fraction of their wealth invested in a particular pension scheme. In essence, this distinction reflects the difference between the Sharpe and Jensen-Treynor-Black approaches to the measurement of performance.

We tested for persistence in performance using a variant of the approach employed by Hendricks, Patel, and Zeckhauser (1993). For December of each year, we sorted the funds into four equal-weighted portfolios based on the rank of their abnormal performance measure over the most recent 12-month period. We record their performance over the subsequent year and repeat the procedure every 12 months. Thus we have returns on four portfolios over 96 months (we used the first twelve months of data to generate the initial abnormal performance estimate. $)^{32}$

Panels A and B of Table 5 provide some evidence of persistence in performance but only in respect of peer-group comparisons and then only for UK equities and cash/other investments. Further, this persistence does not extend beyond a oneyear horizon. For the multi-index benchmark case, the individual alphas from the quartile-sorted Jensen regressions are insignificant at conventional levels, although the difference between the annualized alphas of the highest and lowest past-performance portfolios for UK equities is 126 basis points. This regularity is also reflected in the peer-group benchmark-adjusted returns, where the corre-

\footnotetext{
${ }^{31}$ In contrast, Lehmann and Modest (1987), Grinblatt and Titman (1992), Lakonishok, Shleifer and Vishny (1992a), Hendricks, Patel, and Zeckhauser (1993), and Brown and Goetzmann (1995) find persistence in the performance of (mainly) the worst-performing mutual funds in the US.

${ }^{32}$ On average each of the four portfolios contained around 80 funds for UK equities, international equities, cash/other investments and total holdings and somewhat fewer funds for the other asset classes.
} 
sponding annualized average raw return differential for UK equities is 146 basis points. The sample means are also ordered from largest to smallest across the four quartiles.

Panel $\mathrm{C}$ of Table 5 provides an alternative characterization of the persistence of abnormal performance. We formed zero net investment portfolios each December by taking a long position in those funds that had positive alphas over the previous year and a short position in those that had negative alphas, and tracked the performance of these constructed portfolios over the subsequent twelve months, in a manner similar to Brown, Goetzmann, Ibbotson, and Ross (1992) and Hendricks, Patel, and Zeckhauser (1993). The results remain consistent with the hypothesis that there is measured persistence in UK equity returns. Once again, the magnitude of the effect with UK equities is modest, of the order of 0.5 per cent annualized.

Of course, fund size partly reflects cumulative past performance, while our previous-year-return measure reflects recent performance. That these two effects are interrelated shows up in portfolio composition: only 15 per cent of the quartile containing the smallest funds were also in the quartile of worst-performing funds, whereas 32 per cent of the largest funds were contained in this quartile. Evidence such as this makes it hard to tell if size is the anchor of current performance or the result of good previous performance.

In an attempt to disentangle the two effects, we ran single-index Jensen regressions for each UK equity portfolio, with the portfolio's own (size-adjusted or/and past-performance-adjusted) quartile return included as an additional regressor. This procedure can be justified on the grounds that the single index regressions omitted some important risk factor and that the betas on the size- and/or pastperformance-adjusted quartile portfolios are constant. The results covering the period 1987-1994 (96 months) are presented in Table 6. One year of data are lost due to the initial sort. The 5 - 95 per cent range for the alpha estimates, based on the standard benchmark regression, is 400 basis points from -1.86 to 2.11 per cent. When the funds' size-sorted-quartile portfolio returns were included in the regression, this range fell substantially to 319 basis points. However, the range only fell to 374 basis points when the corresponding past-performance-sorted portfolios were included. Fund size thus accounts for a non-trivial proportion of the cross-sectional variation in abnormal performance, while past performance does not. Perhaps size is, after all, the real anchor of performance. 


\section{Conclusion}

UK pension fund managers have not exploited the investment freedoms given to them by pension plan trustees. Instead, two of the four key regularities documented in this paper - a narrow dispersion of returns around the median fund manager and the slight underperformance of the median fund manager compared with the market average - appear to be the result of the incentive effects of the fee structures, the performance evaluation environment operating, and the degree of concentration in the UK pension fund industry during our sample period. The fee structures provided a very weak incentive to add value, while relative performance evaluation provided a strong incentive to avoid underperforming the median fund manager $^{33}$. At the same time, the incentive to implement independent investment strategies that deviated significantly from that of the median fund manager was severely limited by the highly concentrated nature of the UK fund management industry. The third and fourth key regularities - the outperformance of the median fund manager from our sample of long-standing fund managers compared with the peer-group average (especially in UK equities) and the relative underperformance of large funds - can be explained by a fund size effect. Hence, most managers could point to their above-average performance or to plausible reasons for underperformance. Thus it is perhaps unsurprising that we find that managers produced remarkably little cross-sectional variation in overall ex post performance and were generally able to retain their mandates. What is more surprising is how they were able to demand active management fees when their performance clearly indicated that passive management fees would have been more appropriate.

The contrast with the US is striking. The study by Lakonishok, Shleifer and Vishny (1992a) of US equity pension fund managers shows a greater degree of market underperformance (130 basis points per year compared with 15 basis points

\footnotetext{
${ }^{33}$ Support for these results can be found in the theoretical literature on agency effects in delegated portfolio management which generates a 'non-incentive' result in the case of linear relative performance evaluation (RPE) contracts (whereby the fund manager's fee is proportional to the excess return above a peer-group benchmark). Such contracts fail to provide managers who are unconstrained in their investment objectives with adequate incentives to search for superior information and hence encourage herding (Dybvig, Farnsworth and Carpenter (2000), Gómez and Sharma (2001)). While UK pension fund managers do not face explicit RPE contracts, their long-term survival depends on implicit RPE contracts and again these provides an incentive to herd around the median fund manager.
} 
for UK equity pension fund managers), while the study by Coggin et al (1993) shows that the dispersion of returns on equity funds is twice as high in the US compared with our findings for the UK (up to 603 basis points for the 10-90 percentile range compared with 311 basis points in the UK). These results are consistent with the low degree of concentration in the US pension fund industry, the greater degree of turnover of fund managers and the much wider range of investment styles compared with the UK. 


\section{References}

[1] Admati, A., Bhattacharya, S., Pfleiderer, P.C., and Ross, S.A. (1986) 'On Timing and Selectivity'. Journal of Finance, 41, 715-30.

[2] Blake, D. (1995) 'Pension Schemes and Pension Funds in the United Kingdom'. Oxford University Press, Oxford.

[3] Blake, D., Lehmann, B., and Timmermann, A. (1999) 'Asset Allocation Dynamics and Pension Fund Performance'. Journal of Business, 72, 429-61.

[4] Brown, G., Draper, P., and McKenzie, E. (1997) 'Consistency of UK Pension Fund Investment Performance'. Journal of Business Finance and Accountancy, $24,155-78$.

[5] Brown, K.C., Harlow, W.V., and Starks, L.T. (1996) 'Of Tournaments and Temptations: An Analysis of Managerial Incentives in the Mutual Fund Industry'. Journal of Finance, 51, 85-110.

[6] Brown, S.J., and Goetzmann, W. (1995) 'Performance Persistence'. Journal of Finance, 50, 679-698.

[7] Brown, S.J., Goetzmann, W.N., Ibbotson, R., and Ross, S. (1992). 'Survivorship Bias in Performance Studies'. Review of Financial Studies, 5, 553-580.

[8] Busse, J. (2001) 'Another Look at Mutual Fund Tournaments'. Journal of Financial and Quantitative Analysis, 36, 53-73.

[9] Chevalier, J., and Ellison, G. (1997) 'Risk Taking by Mutual Funds as a Response to Incentives'. Journal of Political Economy, 105, 1167-1200.

[10] Chevalier, J. and Ellison, G. (1999) 'Career Concerns of Mutual Fund Managers'. Quarterly Journal of Economics, 114, 389-432.

[11] Christopherson, J.A., Ferson, W.E., and Glassman, D.A. (1998a) 'Conditioning Manager Alphas on Economic Information: Another Look at the Persistence of Performance'. Review of Financial Studies, 11, 111-142. 
[12] Christopherson, J.A., Ferson, W.E., and Glassman, D.A. (1998b) 'Conditioning Measures of Performance and Persistence for Pension Funds'. In A H Chen (ed.), Research in Finance, 16, 1-46 (JAI Press, Stamford, Ct).

[13] Coggin, T.D., Fabozzi, F.J., and Rahman, S. (1993) 'The Investment Performance of US Equity Pension Fund Managers: An Empirical Investigation'. Journal of Finance, 48, 1039-1055.

[14] Del Guercio, D. (1996) 'The Distorting Effect of Prudent Man Laws on Institutional Equity Investments'. Journal of Financial Economics, 40, 31-62.

[15] Dybvig, P.H., Farnsworth, H.K., and Carpenter, J.N. (2000) 'Portfolio Performance and Agency', Washington University in St Louis, mimeo.

[16] Elton, E.J., Gruber, M.J., Das, S., and Hlavka, M. (1993) 'Efficiency with Costly Information: A Reinterpretation of Evidence from Managed Portfolios'. Review of Financial Studies, 6, 1-22.

[17] Fama, E.F., and MacBeth, J. (1973) 'Risk, Return and Equilibrium: Empirical Tests'. Journal of Political Economy, 81, 607-636.

[18] Ferson, W.E., and Schadt, R.W. (1996). 'Measuring Fund Strategy and Performance in Changing Economic Conditions'. Journal of Finance, 51, 425-462.

[19] Gómez, J-P., and Sharma, T. (2001) 'Providing Managerial Incentives: Do Benchmarks Matter?', Norwegian School of Management, mimeo.

[20] Greene, W. (1999), 'Econometric Analysis'. Prentice-Hall International, London.

[21] Grinblatt, M., and Titman, S. (1989) 'Mutual Fund Performance: An Analysis of Quarterly Portfolio Holdings'. Journal of Business, 62, 393-416.

[22] Grinblatt, M., and Titman, S. (1992) 'The Persistence of Mutual Fund Performance'. Journal of Finance, 47, 1977-1984.

[23] Halpern, P., and Fowler, I. (1991) 'Investment Management Fees and the Determinants of Pricing and Structure in the Industry'. Journal of Portfolio Management, Winter, 74-79. 
[24] Hendricks, D., Patel, J., and Zeckhauser, R. (1993) 'Hot Hands in Mutual Funds: Short-run Persistence of Relative Performance, 1974-88'. Journal of Finance, 48, 93-130.

[25] Hong, H., J.D. Kubik and A. Solomon (2000) 'Security Analysts' Career Concerns and Herding of Earnings Forecasts'. Rand Journal of Economics, 31, 121-144.

Jensen, M. C., (1972) 'Optimal Utilization of Market Forecasts and the Evaluation of Investment Portfolio Performance'. In G.P. Szego and Karl Shell (eds.), 'Mathematical Methods in Investment and Finance'. North-Holland: Amsterdam, 310-35.

[26] Kay, J., Laslett, R., and Duffy, N. (1994) 'The Competitive Advantage of the Fund Management Industry in the City of London'. Subject Report 9, The City Research Project, Corporation of London, London.

[27] Lakonishok, J., Shleifer, A., Vishny, R.W. (1992a) 'The Structure and Performance of the Money Management Industry'. Brookings Papers: Microeconomics, 339-91.

[28] Lakonishok, J., A. Shleifer, and R.W. Vishny (1992b) 'The Impact of Institutional Trading on Stock Prices'. Journal of Financial Economics, 32, 23-43.

[29] Lambert, E. (1998) 'Herding Instinct'. Pension Management, January, 44-45.

[30] Lehmann, B.N. and Modest, D.M. (1987), 'Mutual Fund Performance Evaluation: A Comparison of Benchmarks and Benchmark Comparisons'. Journal of Finance, 42, 233-65.

[31] Malkiel, B.G. (1995) 'Returns from Investing in Equity Mutual Funds, 1971 to 1991'. Journal of Finance, 50, 549-572.

[32] Newey, W.K., and West, K.D. (1987) 'A Simple, Positive Semi-Definite Heteroskedasticity- and Autocorrelation-Consistent Covariance Matrix'. Econometrica, 55 703-708.

[33] Pesaran, M.H. and Timmermann, A. (1995) 'Predictability of Stock Returns: Robustness and Economic Significance'. Journal of Finance, 50, 1201-1228. 
[34] Prosser, D. (1995) 'Segregated Funds: The Big Game Hunt is Over'. Pensions Management, March, 45-62.

[35] Shanken, J. (1992) 'On the Estimation of Beta Pricing Models'. Review of Financial Studies, 5, 1-33.

[36] Sirri, E. and P. Tufano (1998) 'Costly Search and Mutual Fund Flows'. Journal of Finance, 1589-1622.

[37] Stevenson, M. (1993) 'Investment Management Survey'. The Economist (November 27).

[38] Thomas, A., and Tonks, I. (2000) 'Equity Performance and Segregated Pension Funds in the UK', Discussion Paper 00/26, Centre for Market and Public Organisation, University of Bristol.

[39] Treynor, J. and Mazuy, F. (1966) 'Can Mutual Funds Outguess the Market?'. Harvard Business Review, 44, 131-136.

[40] Trueman, B. (1994) 'Analyst Forecast and Herding Behavior.' Review of Financial Studies 7, 97-124.

[41] Zwiebel, J. (1995) 'Corporate Conservatism and Relative Compensation'. Journal of Political Economy, 103, 1-25. 
Table 1. Fractiles of Total and Risk-Adjusted Returns by Asset Class, 1986-1994. (Average Annual Percentages)

\begin{tabular}{|c|c|c|c|c|c|c|c|c|}
\hline & $\begin{array}{r}\text { UK } \\
\text { Equities }\end{array}$ & $\begin{array}{r}\text { Intl. } \\
\text { Equities }\end{array}$ & $\begin{array}{r}\text { UK } \\
\text { Bonds }\end{array}$ & $\begin{array}{r}\text { Intl. } \\
\text { Bonds }\end{array}$ & $\begin{array}{r}\text { UK Index } \\
\text { Bonds }\end{array}$ & $\begin{array}{r}\text { Cash/ } \\
\text { Other Inv. }\end{array}$ & $\begin{array}{r}\text { UK } \\
\text { Property }\end{array}$ & Total \\
\hline \multicolumn{9}{|c|}{ A. Total Returns } \\
\hline Minimum & 8.59 & 4.42 & 6.59 & -0.64 & 5.59 & 2.67 & 3.05 & 7.22 \\
\hline $5 \%$ & 11.43 & 8.59 & 9.44 & 2.18 & 7.20 & 5.46 & 5.07 & 10.60 \\
\hline $10 \%$ & 11.85 & 9.03 & 9.95 & 7.56 & 7.81 & 7.60 & 6.58 & 10.96 \\
\hline $25 \%$ & 12.44 & 9.64 & 10.43 & 8.30 & 7.91 & 8.97 & 8.03 & 11.47 \\
\hline $50 \%$ & 13.13 & 10.65 & 10.79 & 11.37 & 8.22 & 10.25 & 8.75 & 12.06 \\
\hline $75 \%$ & 13.93 & 11.76 & 11.22 & 13.37 & 8.45 & 11.72 & 9.99 & 12.59 \\
\hline $90 \%$ & 14.81 & 12.52 & 11.70 & 14.55 & 8.80 & 14.20 & 10.84 & 13.13 \\
\hline $95 \%$ & 15.46 & 13.14 & 12.05 & 18.15 & 8.89 & 16.13 & 11.36 & 13.39 \\
\hline Maximum & 17.39 & 14.68 & 17.23 & 26.34 & 10.07 & 19.73 & 13.53 & 15.03 \\
\hline \multicolumn{9}{|c|}{ B. Risk-Adjusted Returns (Equation (1)) } \\
\hline Minimum & -4.59 & -6.19 & -3.59 & -10.08 & -2.49 & -7.60 & -6.72 & -4.98 \\
\hline $5 \%$ & -1.90 & -2.17 & -0.92 & -6.74 & -0.95 & -4.53 & -3.69 & -1.77 \\
\hline $10 \%$ & -1.49 & -1.69 & -0.42 & -1.89 & -0.65 & -2.76 & -2.57 & -1.36 \\
\hline $25 \%$ & -0.85 & -0.96 & 0.07 & -1.11 & -0.16 & -0.97 & -0.90 & -0.79 \\
\hline $50 \%$ & -0.15 & -0.06 & 0.44 & 1.76 & 0.09 & 0.31 & -0.21 & -0.14 \\
\hline $75 \%$ & 0.70 & 1.07 & 0.87 & 4.38 & 0.28 & 2.13 & 0.94 & 0.39 \\
\hline $90 \%$ & 1.49 & 1.83 & 1.34 & 5.48 & 0.70 & 4.68 & 1.79 & 0.89 \\
\hline $95 \%$ & 2.14 & 2.36 & 1.72 & 8.36 & 0.75 & 10.02 & 2.31 & 1.22 \\
\hline Maximum & 4.68 & 4.06 & 6.89 & 16.67 & 1.77 & 12.67 & 4.33 & 3.09 \\
\hline
\end{tabular}

Notes: (i) Panel A shows the fractiles of the cross-sectional distribution of raw returns on individual asset classes as well as on the total portfolios of UK pension funds.

(ii) Panel B shows the fractiles of the cross-sectional distribution of estimates of intercept terms from single-factor Jensen regressions of excess returns within a particular asset class on the excess return on the external benchmark for that asset class. 
Table 2. Performance in UK Equities against a Variety of Benchmarks, 1986-1994 (Average Annual Percentages)

\begin{tabular}{|c|c|c|c|c|c|c|}
\hline & $\begin{array}{r}\text { Unconditional } \\
\text { Alpha }\end{array}$ & $\begin{array}{l}\text { Condit } \\
\text { (Ferson- } \\
\text { Schadt) }\end{array}$ & $\begin{array}{r}\text { tional Alpha } \\
\text { (Christopherson } \\
\text { et al) }\end{array}$ & $\begin{array}{l}\text { Small Cap- } \\
\text { Adjusted }\end{array}$ & $\begin{array}{r}\text { Treynor- } \\
\text { Mazuy }\end{array}$ & $\begin{array}{r}\text { Peer-group } \\
\text { Adjusted }\end{array}$ \\
\hline Minimum & -4.59 & -3.85 & -6.54 & -4.70 & -5.07 & -4.19 \\
\hline $5 \%$ & -1.90 & -1.95 & -1.61 & -1.87 & -1.79 & -1.35 \\
\hline $10 \%$ & -1.49 & -1.58 & -1.18 & -1.44 & -1.51 & -0.92 \\
\hline $25 \%$ & -0.85 & -0.91 & -0.44 & -0.83 & -0.81 & -0.33 \\
\hline $50 \%$ & -0.15 & -0.17 & 0.29 & -0.14 & -0.07 & 0.35 \\
\hline $75 \%$ & 0.70 & 0.58 & 1.03 & 0.68 & 0.74 & 1.16 \\
\hline $90 \%$ & 1.49 & 1.36 & 2.09 & 1.51 & 1.60 & 2.03 \\
\hline $95 \%$ & 2.14 & 1.90 & 2.55 & 2.15 & 2.06 & 2.69 \\
\hline Maximum & 4.68 & 3.92 & 8.13 & 4.78 & 4.08 & 4.62 \\
\hline Range of $A$ & & & & & & \\
\hline Positiv & 140 & 136 & 177 & 139 & 148 & 194 \\
\hline (of which si & (24) & (13) & (24) & (27) & (21) & (48) \\
\hline Negat & 166 & 170 & 129 & 167 & 158 & 112 \\
\hline (of which significant) & (29) & (27) & (12) & (27) & (25) & (13) \\
\hline Bonferroni & & & & & & \\
\hline Minimu & -5.18 & -5.93 & -5.24 & -6.90 & -5.08 & -3.91 \\
\hline & $(<0.0001)$ & $(<0.0001)$ & $(<0.0001)$ & $(<0.0001)$ & $(<0.0001)$ & $(0.0138)$ \\
\hline Maximum t-value & 5.11 & 3.90 & 4.14 & 5.65 & 4.74 & 6.35 \\
\hline (p-value) & $(<0.0001)$ & $(0.0146)$ & $(0.0052)$ & $(<0.0001)$ & $(0.0003)$ & $(<0.0001)$ \\
\hline $\begin{array}{c}\text { Average Alpha Estimate } \\
\text { (t-value) }\end{array}$ & $\begin{array}{l}-0.047 \\
(-0.22)\end{array}$ & $\begin{array}{l}-0.127 \\
(-0.57)\end{array}$ & $\begin{array}{l}0.332 \\
(0.66)\end{array}$ & $\begin{array}{l}-0.022 \\
(-0.10)\end{array}$ & $\begin{array}{l}-0.001 \\
(-0.01)\end{array}$ & $\begin{array}{l}0.459 \\
(4.04)\end{array}$ \\
\hline
\end{tabular}

Note: This table reports the cross-sectional distribution of alpha estimates from Jensen regressions. The unconditional Jensen regression gives the alpha estimate from a regression of the funds' equity excess returns on the excess return on the market index. The conditional Jensen regressions refine the standard equation by allowing the beta (and alpha) to depend linearly on a set of predetermined factors (Ferson-Schadt (1996) and Christopherson et al (1998a), respectively). In addition to using excess returns on the market index as a regressor, the small cap regression also includes returns on a small cap index. The Treynor-Mazuy (1996) model uses as regressors an intercept term and the level and squared value of the excess return on the market index. The peer-group model simply subtracts peer-group returns from the pension funds' equity returns. All alphas are in annualized percentage terms. Alpha estimates are counted as being significant provided their coefficients are statistically significant at the 5 per cent critical level. 
Table 3. Fractiles of Truncation-Adjusted Performance Estimates for UK Equities, 1986-1994. (Average Annual Percentages)

\begin{tabular}{|crrrrrr|}
\hline & \multicolumn{3}{c}{ UK Equity } & \multicolumn{3}{c|}{ Total return } \\
& No Censoring & \multicolumn{2}{c}{ Censoring (per month) } & No Censoring & \multicolumn{2}{c|}{ Censoring (per month) } \\
& & $-1 \%$ & $-5 \%$ & & $-1 \%$ & $-5 \%$ \\
\hline Minimum & -4.59 & -4.74 & -4.60 & -4.98 & -5.15 & -5.00 \\
$5 \%$ & -1.90 & -1.90 & -1.90 & -1.77 & -1.78 & -1.77 \\
$10 \%$ & -1.49 & -1.50 & -1.49 & -1.36 & -1.37 & -1.36 \\
$25 \%$ & -0.84 & -0.86 & -0.84 & -0.79 & -0.80 & -0.79 \\
$50 \%$ & -0.15 & -0.17 & -0.15 & -0.14 & -0.16 & -0.16 \\
$75 \%$ & 0.70 & 0.70 & 0.70 & 0.39 & 0.39 & 0.39 \\
$90 \%$ & 1.49 & 1.48 & 1.49 & 0.89 & 0.89 & 0.89 \\
$95 \%$ & 2.14 & 2.14 & 2.14 & 1.22 & 1.21 & 1.22 \\
Maximum & 4.68 & 4.60 & 4.68 & 3.09 & 3.07 & 3.09 \\
\hline
\end{tabular}

Note: This table shows maximum likelihood estimates of Jensen's alpha based on the model that allows for survivor bias. 
Table 4. UK Pension Funds' Alpha Values in Different Asset Categories: Quartile-Sorted According to Fund Size, 1986-1994 (Average Annual Percentages).

\begin{tabular}{|c|c|c|c|c|c|c|c|c|c|}
\hline Quartile & $\begin{array}{c}\text { UK } \\
\text { Equities }\end{array}$ & $\begin{array}{r}\text { Intl. } \\
\text { Equities }\end{array}$ & $\begin{array}{r}\text { UK } \\
\text { Bonds }\end{array}$ & $\begin{array}{r}\text { Intl. } \\
\text { Bonds }\end{array}$ & $\begin{array}{r}\text { Index } \\
\text { Bonds }\end{array}$ & $\begin{array}{r}\text { Cash/ } \\
\text { Other Inv. }\end{array}$ & $\begin{array}{r}\text { UK } \\
\text { Property }\end{array}$ & $\begin{array}{r}\text { Intl. } \\
\text { Property }\end{array}$ & Tota \\
\hline \multicolumn{10}{|c|}{ A. Multi-Index Benchmark (Equation (3)) } \\
\hline \multirow[t]{2}{*}{ I (Smallest) } & 0.352 & -3.189 & 0.676 & -3.989 & 0.106 & 0.53 & -0.999 & NA & -0.315 \\
\hline & $(0.91)$ & $(-1.28)$ & $(1.00)$ & $(-1.20)$ & $(0.31)$ & $(0.73)$ & $(-0.98)$ & NA & $(-0.47)$ \\
\hline \multirow[t]{2}{*}{ II } & 0.063 & -2.492 & 0.575 & -0.805 & -0.344 & 1.545 & -0.384 & NA & -0.360 \\
\hline & $(0.16)$ & $(-1.13)$ & $(0.92)$ & $(-0.35)$ & $(-0.52)$ & $(1.57)$ & $(-0.36)$ & NA & $(-0.59)$ \\
\hline \multirow[t]{2}{*}{ III } & 0.213 & -1.464 & 1.130 & -1.886 & 0.074 & 0.764 & -0.937 & NA & 0.110 \\
\hline & $(0.68)$ & $(-0.76)$ & $(1.69)$ & $(-0.85)$ & $(0.23)$ & $(0.93)$ & $(-1.15)$ & NA & $(0.21)$ \\
\hline \multirow[t]{2}{*}{ IV (Largest) } & -0.435 & -1.041 & 0.249 & 2.247 & 0.137 & 0.247 & -0.334 & NA & -0.268 \\
\hline & $(-1.36)$ & $(-0.60)$ & $(0.28)$ & $(0.91)$ & $(0.46)$ & $(0.29)$ & $(-0.26)$ & NA & $(-0.53)$ \\
\hline \multicolumn{10}{|c|}{ B. Peer-Group Benchmark (Equation (2)) } \\
\hline \multirow[t]{2}{*}{ I (Smallest) } & 0.716 & -0.421 & 0.496 & -1.631 & 0.306 & 0.733 & -1.064 & -0.396 & 0.311 \\
\hline & $(4.60)$ & $(-0.33)$ & $(1.20)$ & $(-0.60)$ & $(0.89)$ & $(1.07)$ & $(-1.39)$ & $(-0.10)$ & $(1.23)$ \\
\hline \multirow[t]{2}{*}{ II } & 0.456 & -0.396 & 0.298 & -1.245 & -0.273 & 1.056 & -0.396 & -4.356 & 0.157 \\
\hline & (2.75) & $(-0.58)$ & $(0.92)$ & $(-0.73)$ & $(-0.51)$ & (1.23) & $(-0.48)$ & $(-0.64)$ & $(0.88)$ \\
\hline \multirow[t]{2}{*}{ III } & 0.503 & 0.103 & 0.737 & -1.161 & 0.287 & 0.633 & -0.794 & -0.804 & 0.422 \\
\hline & $(4.36)$ & $(0.51)$ & $(2.68)$ & $(-0.61)$ & (1.05) & (0.95) & $(-1.30)$ & $(-0.18)$ & (3.69) \\
\hline \multirow[t]{2}{*}{ IV (Largest) } & 0.027 & 0.439 & 0.175 & 1.271 & 0.283 & 0.702 & -0.668 & 1.920 & 0.037 \\
\hline & $(0.19)$ & $(1.26)$ & $(0.28)$ & $(0.52)$ & $(1.20)$ & (1.03) & $(-1.00)$ & $(0.62)$ & $(0.15)$ \\
\hline
\end{tabular}

Note: Based on their size at the beginning of each year, the funds were sorted into quartiles, and four equal-weighted portfolios were formed for the following calendar year corresponding to the smallest group of funds (quartile I), the second smallest group of funds (quartile II), and so forth. This procedure was repeated each calendar year, generating four time series, each with 96 observations. For these portfolios Jensen regressions were used to estimate the mean of the risk-adjusted returns. These alpha estimates are reported in Panel $A$ in the case of the multi-index benchmark and in Panel B in the case of the peer-group benchmark. The reported figures measure the alpha estimates of the portfolios, with the figures in brackets showing the t-values based on Newey-West (1987) heteroskedasticity- and autocorrelation-consistent standard errors. 
Table 5. UK Pension Funds' Alpha Values in Different Asset Categories: Quartile-Sorted According to Previous-Year Returns, 1986-1994 (Average Annual Percentages).

\begin{tabular}{|c|c|c|c|c|c|c|c|c|c|}
\hline Quartile & $\begin{array}{c}\text { UK } \\
\text { Equities } \\
\end{array}$ & $\begin{array}{r}\text { Intl. } \\
\text { Equities } \\
\end{array}$ & $\begin{array}{r}\text { UK } \\
\text { Bonds } \\
\end{array}$ & $\begin{array}{r}\text { Intl. } \\
\text { Bonds }\end{array}$ & $\begin{array}{r}\text { Index } \\
\text { Bonds } \\
\end{array}$ & $\begin{array}{r}\text { Cash/ } \\
\text { Other Inv. }\end{array}$ & $\begin{array}{r}\text { UK } \\
\text { Property } \\
\end{array}$ & $\begin{array}{r}\text { Intl. } \\
\text { Property }\end{array}$ & Total \\
\hline \multicolumn{10}{|c|}{ A. Multi-Index Benchmark (Equation (3)) } \\
\hline I (Highest) & $\begin{array}{l}0.574 \\
(1.55)\end{array}$ & $\begin{array}{l}-1.880 \\
(-0.88)\end{array}$ & $\begin{array}{l}0.771 \\
(1.08)\end{array}$ & $\begin{array}{l}-1.345 \\
(-0.48)\end{array}$ & $\begin{array}{l}0.216 \\
(0.68)\end{array}$ & $\begin{array}{r}1.464 \\
(1.79)\end{array}$ & $\begin{array}{l}-0.953 \\
(-0.77)\end{array}$ & $\begin{array}{l}\text { NA } \\
\text { NA }\end{array}$ & $\begin{array}{l}0.007 \\
(0.01)\end{array}$ \\
\hline II & $\begin{array}{l}0.243 \\
(0.75)\end{array}$ & $\begin{array}{l}-1.908 \\
(-0.93)\end{array}$ & $\begin{array}{l}0.585 \\
(0.89)\end{array}$ & $\begin{array}{l}1.761 \\
(0.94)\end{array}$ & $\begin{array}{l}-0.296 \\
(-0.46)\end{array}$ & $\begin{array}{l}0.315 \\
(0.51)\end{array}$ & $\begin{array}{l}-0.162 \\
(-0.16)\end{array}$ & $\begin{array}{l}\text { NA } \\
\text { NA }\end{array}$ & $\begin{array}{l}-0.247 \\
(-0.46)\end{array}$ \\
\hline III & $\begin{array}{l}0.071 \\
(0.21)\end{array}$ & $\begin{array}{l}-1.843 \\
(-0.77)\end{array}$ & $\begin{array}{r}1.017 \\
(1.90)\end{array}$ & $\begin{array}{l}-0.698 \\
(-0.32)\end{array}$ & $\begin{array}{r}0.081 \\
'(0.20)\end{array}$ & $\begin{array}{l}0.448 \\
(0.39)\end{array}$ & $\begin{array}{l}-0.983 \\
(-0.96)\end{array}$ & $\begin{array}{l}\text { NA } \\
\text { NA }\end{array}$ & $\begin{array}{l}-0.217 \\
(-0.38)\end{array}$ \\
\hline IV (Lowest) & $\begin{array}{l}-0.688 \\
(-1.74)\end{array}$ & $\begin{array}{l}-2.534 \\
(-1.08)\end{array}$ & $\begin{array}{l}0.261 \\
(0.30)\end{array}$ & $\begin{array}{l}-4.151 \\
(-1.67)\end{array}$ & $\begin{array}{l}-0.008 \\
(-0.03)\end{array}$ & $\begin{array}{l}0.849 \\
(0.96)\end{array}$ & $\begin{array}{l}-0.556 \\
(-0.62)\end{array}$ & $\begin{array}{l}\text { NA } \\
\text { NA }\end{array}$ & $\begin{array}{l}-0.373 \\
(-0.59)\end{array}$ \\
\hline \multicolumn{10}{|c|}{ B. Peer-Group Benchmark (Equation (2)) } \\
\hline I (Highest) & $\begin{array}{l}1.145 \\
(5.37)\end{array}$ & $\begin{array}{l}0.264 \\
(0.55)\end{array}$ & $\begin{array}{l}0.818 \\
(2.03)\end{array}$ & $\begin{array}{l}-2.572 \\
(-0.94)\end{array}$ & $\begin{array}{l}-0.194 \\
(-0.32)\end{array}$ & $\begin{array}{l}2.366 \\
(2.42)\end{array}$ & $\begin{array}{l}-0.295 \\
(-0.47)\end{array}$ & $\begin{array}{l}4.092 \\
(0.95)\end{array}$ & $\begin{array}{l}0.331 \\
(1.27)\end{array}$ \\
\hline II & $\begin{array}{l}0.604 \\
(4.75)\end{array}$ & $\begin{array}{l}0.068 \\
(0.10)\end{array}$ & $\begin{array}{l}0.335 \\
(1.12)\end{array}$ & $\begin{array}{l}1.325 \\
(0.68)\end{array}$ & $\begin{array}{l}0.275 \\
(1.44)\end{array}$ & $\begin{array}{l}1.117 \\
(2.25)\end{array}$ & $\begin{array}{l}-0.597 \\
(-0.80)\end{array}$ & $\begin{array}{l}2.508 \\
(0.77)\end{array}$ & $\begin{array}{l}0.315 \\
(2.29)\end{array}$ \\
\hline III & $\begin{array}{l}0.275 \\
(2.32)\end{array}$ & $\begin{array}{l}0.086 \\
(0.08)\end{array}$ & $\begin{array}{l}0.367 \\
(1.15)\end{array}$ & $\begin{array}{l}-1.291 \\
(-0.80)\end{array}$ & $\begin{array}{l}0.184 \\
(1.05)\end{array}$ & $\begin{array}{l}0.215 \\
(0.23)\end{array}$ & $\begin{array}{l}-1.129 \\
(-1.92)\end{array}$ & $\begin{array}{l}-0.120 \\
(-0.03)\end{array}$ & $\begin{array}{l}0.211 \\
(1.55)\end{array}$ \\
\hline IV (Lowest) & $\begin{array}{l}-0.313 \\
(-1.72)\end{array}$ & $\begin{array}{l}-0.677 \\
(-1.18)\end{array}$ & $\begin{array}{l}0.187 \\
(0.30)\end{array}$ & $\begin{array}{l}-0.229 \\
(-0.12)\end{array}$ & $\begin{array}{l}0.331 \\
(0.98)\end{array}$ & $\begin{array}{l}-0.555 \\
(-0.76)\end{array}$ & $\begin{array}{l}-0.903 \\
(-1.12)\end{array}$ & $\begin{array}{r}1.092 \\
(-0.33)\end{array}$ & $\begin{array}{l}0.069 \\
(0.30)\end{array}$ \\
\hline C. Zero Net & ent Portfol & & & & & & & & \\
\hline Multi-Index & $\begin{array}{l}0.458 \\
(4.18)\end{array}$ & $\begin{array}{l}1.214 \\
(0.68)\end{array}$ & $\begin{array}{l}-0.105 \\
(-0.47)\end{array}$ & $\begin{array}{l}0.349 \\
(1.82)\end{array}$ & $\begin{array}{l}0.015 \\
(1.49)\end{array}$ & $\begin{array}{l}6.334 \\
(1.50)\end{array}$ & $\begin{array}{l}-0.009 \\
(-0.03)\end{array}$ & $\begin{array}{l}\text { NA } \\
\text { NA }\end{array}$ & $\begin{array}{l}0.151 \\
(0.85)\end{array}$ \\
\hline Peer-Group & $\begin{array}{r}0.478 \\
(5.23) \\
\end{array}$ & $\begin{array}{l}0.257 \\
(0.69) \\
\end{array}$ & $\begin{array}{r}0.115 \\
(1.30) \\
\end{array}$ & $\begin{array}{r}-0.219 \\
(-1.24) \\
\end{array}$ & $\begin{array}{l}0.003 \\
(0.33) \\
\end{array}$ & $\begin{array}{l}2.246 \\
(1.10) \\
\end{array}$ & $\begin{array}{l}0.094 \\
(0.30) \\
\end{array}$ & $\begin{array}{l}0.120 \\
(0.82) \\
\end{array}$ & $\begin{array}{l}0.056 \\
(0.49) \\
\end{array}$ \\
\hline
\end{tabular}

Notes: (i) At the end of each calendar year, benchmark-adjusted returns were computed for the assets held by the pension funds in the sample. Based on their mean risk-adjusted returns, the funds were then sorted into quartiles, and four equal-weighted portfolios were formed for the following calendar year corresponding to the best-performing quartile (quartile I), the second best-performing funds (quartile II), and so forth. This procedure was repeated each calendar year, generating four time series, each with 96 observations. For these portfolios, Jensen regressions were used to estimate the mean of the risk-adjusted returns. These alpha estimates are reported in Panel $A$ in the case of the multi-index benchmark and in Panel B in the case of the peer-group benchmark.

(ii) The zero net investment portfolios were based on a similar procedure, except that a single portfolio with long positions in funds that historically had a positive estimate of alpha, and short positions in funds with a negative alpha estimate, were formed so that the net cost of the portfolio equals zero. As in panels $\mathrm{A}$ and $\mathrm{B}$, the reported figures in Panel $\mathrm{C}$ measure the alpha estimates of the resulting portfolios, with the figures in brackets showing the t-values based on Newey-West (1987) heteroskedasticity- and autocorrelation-consistent standard errors. 
Table 6. Fractiles of Alpha Estimates, Correcting for Size- and Past-Performance-Sorted Quartile Effects, 1987-1994 (Average Annual Percentages).

\begin{tabular}{|lcccc|}
\hline & Benchmark & Benchmark & Benchmark & Benchmark, Size \\
Only & \& Size & \& Past Performance & \& Past Performance \\
Minimum & -5.24 & -5.18 & -5.24 & -5.23 \\
$5 \%$ & -1.86 & -1.54 & -1.82 & -1.70 \\
$10 \%$ & -1.27 & -1.02 & -1.29 & -1.19 \\
$25 \%$ & -0.75 & -0.54 & -0.74 & -0.59 \\
$50 \%$ & -0.04 & -0.10 & -0.02 & -0.10 \\
$75 \%$ & 0.69 & 0.55 & 0.70 & 0.57 \\
$90 \%$ & 1.63 & 1.31 & 1.56 & 1.38 \\
$95 \%$ & 2.11 & 1.65 & 1.92 & 1.84 \\
Maximum & 4.62 & 3.86 & 4.85 & 4.73 \\
Range of Alpha Estimates: & & & & \\
$\quad$ Positive & 147 & 134 & 148 & 140 \\
(of which significant) & $(30)$ & $(17)$ & $(29)$ & $(25)$ \\
$\quad$ Negative & 159 & 172 & 158 & 166 \\
(of which significant) & $(19)$ & $(18)$ & $(27)$ & $(22)$ \\
Bonferroni Bounds & & & & -4.67 \\
Minimum t-value & -4.74 & -3.75 & -5.00 & $(0.0004)$ \\
$\quad$ ( $p$-value) & $(0.0003)$ & $(0.0271)$ & $(<0.0001)$ & 3.77 \\
Maximum t-value & 4.40 & 3.91 & 4.31 & $(0.0248)$ \\
(p-value) & $(0.0017)$ & $(0.0144)$ & $(0.0025)$ & \\
\hline
\end{tabular}

Note: At the beginning of each year, the funds were sorted into quartiles based on either current size or risk-adjusted performance over the previous year. For the subsequent 12month period, excess returns on the corresponding equal-weighted-quartile portfolios were computed and the procedure repeated to get monthly time series of excess returns for the period 1987-1994. Alpha estimates were computed from regressions of a given fund's excess returns on an intercept, excess returns on the market portfolio, and the excess returns on the quartile-sorted portfolio to which the fund belonged during a given year. The table reports the cross-sectional distribution of these alpha estimates. An estimate is counted as being significant if its coefficient is statistically significant at the 5 per cent critical level. 